\title{
Kemunculan Islam dalam Kesarjanaan Revisionis
}

The Emergency of Islam in Revisionist Scholarship

DOI 10.18196/AIIJIS.2019.0099.135-139

ROBIST HIDAYAT ${ }^{1}$, NADYA RIZKY ${ }^{2}$

Universitas Muhammadiyah Yogyakarta1,2

$\begin{array}{ll}\text { Judul } & \text { : Kemunculan Islam dalam Kesarjanaan Revisionis } \\ \text { Penulis } & : \text { M un'im Sirry } \\ \text { Penerbit } & : \text { Suka Press } \\ \text { Kota } & : \text { Yogyakarta } \\ \text { Tahun } & : 2017 \\ \text { Halaman } & : 332 \\ \text { ISBN } & : 978-602-1326-62-6\end{array}$

Karya Mun'im Sirry ini merupakan pembahasan kemunculan Islam dalam kesarjanaan revisionis kejadian-kejadian masa lalu secara kritis. Yang menjadi fokus adalah sejauh mana catatan sejarawan M uslim awal merupakan catatan yang akurat hanya karena ditulis pada zaman Nabi M uhammad SAW dan lama setelahnya. Apakah informasi yang kita terima dapat dipertanggungjawabkan secara akademis? Mun'im Sirry berusaha menyampaikan bahwa kelahiran dan perkembangan agama Islam sebenarnya lebih lengkap dan kaya dibanding pengetahuan kita saat ini. Buku ini akan membahas tema tersebut dengan terperinci.

Di sini Sirry memaparkan tujuan penjelasan dari berbagai ulasan pokok yang menjadikan para pembaca cukup antusias untuk segera masuk kedalam tiap-tiap ulasan yang cukup menyentil bagi para pembaca yang menelan mentah-mentah informasi yang baru disampaikan. Selain itu adanya konsep-konsep kunci dalam diskursus pemikiran Islam modern di antaranya, yakni tajdid (pembaharuan), ihya' (revival), dan yang terakhir islah (reformasi) yang diasosiasikan sebagai pondasi dalam penghidupan spirit Islam kaum salaf al-salih. Sirry membahas tentang kesarjanaan yang 
lahir tahun 1970 an yang menjadi bagian penting dalam membongkar titik kelemahan narasi tradisional yang sudah berakar dengan kuat. Sebagai contoh yakni sarjana kenamaan asal inggris John Wansbrough yang menerbitkan karyanya yang berjudul Quranic Studies ( 1977) dan The Sectraian Milieu (1978). Penulis juga menyampaikan tujuannya dalam menulis buku ini yaitu; mengajukan sebuah prespektif tentang proses kemunculan Islam ke atas panggung sejarah. Selain itu adanya ketersinggungan tiga aspek yang ada pada kemunculan Islam di antaranya adalah sejarah al-Qur'an, sirah Nabawiyah dan ekspansi perluasan politik.

Pada bagian awal Sirry mengajak para pembaca untuk menelaah latar belakang kesarjanaan baru yang mencoba merevisi apa yang telah diimani oleh kesarjanaan tradisional. Secara tegas Sirry memfokuskan pembahasan ini pada jantung masalah dari kaum tradisional dan kaum revisionis dalam menggunakan sumber-sumber terdahulu untuk merekonstruksi sejarah Islam, data -data dalam Islam sangat sedikit sehingga mencuatkan potret yang sebenarnya tentang Islam dan kemunculan serta perkembangannya. Hal ini diperkuat oleh Sirry mengenai sejarah Islam yang ternyata ditulis pada masa tabi' in atau beberapa generasi setelah Nabi Muhammad, dalam penjabaran suatu peristiwa dan menjadi kabur akan keasliannya. Banyak sumber-sumber yang ditulis sejarawan Muslim belum dapat dikatagorikan sebagai sumber ilmiah karena beberapa peristiwa berbenturan dengan peristiwa lainya pada waktu yang sama. Selain itu data-data dari luar tradisi Islam juga sangat sulit untuk dilacak keberadaanya sehingga menimbulkan berbagai keraguan dan memancing para ilmuan barat untuk melakukan berbagai kritik. Para sarjana barat berani menawarkan potret islam awal yang sama sekali berbeda dari penjelasan tradisional. Sirry juga menyinggung perbedaan pendapat dan pendekatan para sarjana terhadap sumbersumber M uslim yang berdampak serius terhadap perbedaan potret islam di awal, hal ini merupakan kesekuensi logis semata karena potret Islam itu di bayangkan berdasarkan pada dat-data dan informasi yang di peroleh dari berbagai kitab dan sejarah yang ada. Di sini Sirry menyatakan bahwa saat ini apabilah bersinggungan dengan riwayat dan otentik masih bersumber dari isnad dimana di lakukan oleh generasi ke generasi. Banyaknya pendekatan yang dilakukan untuk pembuktian agar semuanya bisa di buktikan. Sirry berpendapat bahwa kekuatan dan kelemahan dari kesarjanaan tradisional dan revisionis seharusnya tidak untuk mencari pembenaran, dan tidak semua sarjana kritis punya motif keagamaan karena 
mereka berangkat dari komitmen intelektual semata untuk mencari buktibukti sejarah yang di anggap terpercaya untuk memperkuat pendapat para sarjana.

Sirry menyoroti kemunculan Islam dari segi teori tradisional dan teori revisionis yang yang menyebabkan beragam tentang kemunculan Islam yang sangat beragam yang menjadi kajian utanma dalam studi islam yang ada di dunia. Ada tiga hal besar yang selalu didiskusikan kalangan revisionis radikal dan kesarjanaan tradisional yaitu; ke-Arab-an dan asal muasal Islam, keterisolasian jazirah Arabia, dan terbentuknya identitas Islam yang begitu singkat karena dalam pembahasan ke dua ini menjadi hal penting jika di bandingkan dengan bahasan pertama yang mungkin menjadi awal kita untuk mencerrmati apa yang akan di sampaikan. Sirry menekankan bahwa situasi kejahiliyahan masyarakat Arab di tanah Arab sebelum Islam sumber-sumber yang berasal secara tradisional berhasil memisahkan ajaran tauhid yang di bawa Nabi dari tradisi agama-agama monoteis sebelumnya, terutama Yahudi dan Kristen. Kesarjanaan revisionis memmperlihatkan pengaruhnya dan mendapatkan momentum sejak tahun 1970. Sirry menceritakan bagaimana orang-orang Kristen dalam aktifitas ekspansi Islam pada saat penaklukan di sisi yang lain adanya perdebatan akademisi barat untuk saling menguji ketajaman analisis, dengan teori-teori keislaman untuk pembuktian, bahkan sarjana Islam pun belum tentu bersedia. Sirry mengajak kita untuk membaca secara detail bagaimana perdebatan para sarjana dengan teori-teori yang sudah di kemukan. Di sini juga di adanya pernyataan jika kita sepenuhnya berpijak pada narasi al-Quran kita kan mendapatkan gambaran berbeda dari pada sumber-sumber tradisional. Secara garis besarnya Sirry berpendapat bahwa Islam bukan hanya muncul secara gradual, melainkan juga tidak tunggal seperti di gambarkan sumbersumber tradisional. Dan yang terakhir Sirry menyatakan sarjana modern

Sirry juga mengupas tentang al-Qur'an. Pedoman hidup dan dasardasar hukum yang tercantum di dalamnya mengundang pembaca untuk terus mencari kebenaran formasi dan kanonisasi al-Qur'an. Sejarah alQur'an tak lepas dari pembahasan bagaimana proses dan sumber-sumber terkumpul sebelum menjadi sebuah mushaf yang kita jumpai setiap hari. Salah satu yang menarik adalah tidak semua yang diterima Nabi Muhammad SAW dapat ditemukan dalam al-Qur'an jika dicermati dari beberapa riwayat seputar pengumpulannya. Adapun beberapa kisah yang muncul lebih dari sekali dengan versi yang membedakan. Scriptio defectiva 
menjadi scriptio plena juga menjadi salah satu sorotan utama begitu juga asbab al-Nuzul yang dianggap sebagai eksegesis dan bukan merupakan sebuah historis. Adanya pembahasan mengenai bible walaupun tidak sebanyak al-Quran menjadi khazanah bacaan yang yang menarik dan kita mengetahui informasi sedikit sebagai informasi tambahan yang sangat bagus. Dimana sudah di mulai informasi yang cukup penting dan banyak yang bisa pembaca dapatkan kan, Sirry dalam bahasan ini mengajak pembaca untuk menegaskan bahwa Islam sebagai doktrin dan institusi yang mengalami perubahaan dan perkembangan yang lebih perlahan di bandingkan yang diyakini M uslim secara tradisional.

Biografi Nabi Muhammad SAW merupakan titik temu yang menjembatani perdebatan secara traditional dan revisionis maka di sini sudah mulai dibahas detailnya. Para tradisional menjadikan biografi Nabi M uhammad SAW sebagai sumber untuk memahami al-Qur'an. Tidak ketinggalan para sarjana barat juga menjadikan periode Mekkah Madinah menjadi bagian penting dari perjalanan hidup Nabi dari dalam kandungan hingga puncak keislaman. Tersirat kontroversi yang terjadi bukanlah dengan Yahudi dan Kristen melainkan dengan orang-orang Arab. Keterbatasan sirah juga tidak luput dari sorotan sarjana dari pembahasan, yang pemilihan narasi atau riwayat lebih menguntungkan dinasti tertentu. Beberapa argumen juga mengatakan bahwa sumber tradisionalis bermasalah dalam hal penulisan biografi yang baru ditulis 150 tahun setelah Nabi wafat. Sumber tradisionalis juga merefleksian perkembangan yng diproyeksikan ke masa Nabi, dan narasi yang bersifat kontraditif. Bgaina ini juga Sirry masih menyematkan argumen-argumen untuk dilacak oleh pemikiran para sarjana-sarjana revisionis yang menemukan bagaimana problematiknya sumbersumber tradisional untuk menyingkatkan apa yang sebenarnya terjadi di zaman Nabi M uhammad SAW bahwa barangkali memang tidak akan ada agama tanpa mitos.

Dan yang terakhir penulis mengupas tentang perjalanan sebuah ajaran menjadi sebuah agama meskipun semua agama akan melalui proses yang panjang sebelum sampai kepada kita. Peluasan dan penyebaran agama menjadi titik terpenting dalam bagian pembahasan, berbagai penaklukan wilayah menjadi salah satu jalan untuk menyebarkan sebuah ajaran karena semua akan tunduk pada yang menguasai wilayah tersebut seperti zaman Nabi M uhammad SAW. M otivasi beragama dianggap menjadi faktor yang mendominasi gerakan ekspansi Islam baik dalam pandangan tradisionalis 
maupun pandangan kesarjanaan modern karena dengan adanya motivasi itu akan tercipta sebuah kondisi yang membuat kita bisa berjuang dengan baik. Sirryjuga menyatakan bahwa pejuang Muslim yang memiliki karakter tersendiri juga menjadi penyebab keberhasilan dalam mengalahkan pasukan lawan yang dari berbagai segi memiliki keunggulan yang lebih. Dalam hal sumber mereka (kaum tradisionalis dan kaum revisoinis) menyadari bahwa tidak ada sumber-sumber yang tidak problematik.

Pada bagian penutup Sirry sedikit banyak ingin menyampaikan bahwa revisionisme perlu dijawab dengan mengkaji berbagai sumber yang mencatat kemunculan dan perkembangan Islam. Sirry juga menegaskan segala cara pandang yang telah ditulisnya dalam buku harus mengarah pada observasi dari berbagai fakta-fakta yang dapat dipertanggung jawabkan. Sirry juga kembali menyinggung bahwa sumber-sumber tradisional memproyeksikan fenomena yang terjadi belakangan seolah-olah terjadi pada periode awal. Sirryjuga memperingatkan untuk menyikapi berbagai sumber baik dari kalangan tradisional dan revisionis secara kritis dan harus dengan hati-hati.

Kelebihan buku ini adalah adanya banyak informasi yang membuka mata kita sebagai pembaca untuk tetap menjadi penganut agama yang cerdas dan kritis terhadap apa yang telah diyakini, terus menelaah dan mencari kebenaran yang sejati sehingga apa yang diyakini dapat dipertanggungjawabkan secara akademis. Buku ini juga mengajak kita untuk lebih dalam lagi mencari dan mempelajari sejarah Islam yang ada sehingga terbuka sumber-sumber yang kita mampu mengungkapkan keganjilankeganjilan yang ada dan berani untuk mengemukakannya tanpa harus menyakiti kepercayaan para tradisionis. Buku ini menjadi hal yang sangat penting bagi para peminat studi Islam maupun studi agama untuk lebih memperluas pengetahuan dan keilmuan tentang Islam. Adanya perbandingan pemahaman antara sarjana yang pemahaman tradisional dan juga revesionis membuat buku ini kaya akan informasi yang menarik. Pemahaman sejarah Islam secara teorits dan juga akademik menjadikan kita berpikir bahwa kejaidna zaman dahulu dan zaman sekarang itu bisa kita teliti dengan informasi yang empiris dan benar. Pada dasarnya buku ini bisa menjadi rujukan untuk melihat Islam dengan pandangan berbeda di di samping dengan penulisnya yang memang ahli dalam bidang ini. Dan menjadi kan buku layak untuk di koleksi dan menjadi literatur untuk penelitian mengenai historical agama Islam.** 
